\title{
METODE DALAM MEMAHAMI HADIS
}

\author{
Oleh: Burhanuddin ${ }^{1}$ \\ ${ }^{1}$ Institut Agama Islam Muhammadiyah Sinjai, \\ Jl.Sultan Hasanuddin. No. 20 Balangnipa, Sinjai
}

\begin{abstract}
Abstrak
Al-Hadis adalah pedoman muslim yang diturunkan dengan menggunakan bahasa Arab, penuh dengan kaidah tata bahasa yang agung dan susunan ungkapan yang sangat indah sehingga ketika akan memahami maksudnya diperlukan penguasaan bahasa Arab tentang bagaimana pemahaman makna dalam menerjemahkannya atau menafsirkannya.Ada beberapa cara dalam menafsirkan atau pemahaman hasits yang dilakukan Para ulama dahulu. telah banyak mencoba melakukan penafsiran atau pemahaman hadis yang terdapat dalam al-Kutub al-Sittah, yakni dengan menulis kitab syarah terhadap kitab tersebut. Namun dari beberapa metode yang dipergunakan oleh para ulama dalam menyusun kitab syarh tersebut dapat diklasifikasikan beberapa metode pemahaman (syarh) hadis, para ulama menggunakan 3 metode, yaitu metode tahlili (analitis), metode ijmāli (global), dan metode muqārin (perbandingan). Ibarat gading tak retak, ketiga metode itu mempunyai kelebihan maupun kelemahan masing-masing. Dengan perkembangan ilmu pengetahuan, maka tak diragukan lagi akan muncul metode maupun pendekatan baru untuk memahami hadis, karena hadis merupakan salah satu sumber pokok hukum Islam kedua setelah al-Qur'an tak kan lepas dari kajian maupun penelitian. Wallahu'alam bi al-sāwāb. Dari metode tersebut dapat memberikan cara agar dapat paham tentang hadist yang akan ditafsirkan.
\end{abstract}

\section{Kata Kunci: Metode, Memahami Hadis}

\section{PENDAHULUAN}

Secara epistemologis, hadis dipandang oleh mayoritas umat Islam sebagai sumber ajaran Islam kedua setelah al-Qur'an. Sebab ia merupakan bayān (penjelas), terhadap ayat-ayat al-Qur'an yang masih mujmal (global), ‘àm (umum) dan yang muthlaq (tanpa batasan). Bahkan secara mandiri hadis dapat berfungsi sebgai penetap (muqarrir) suatu hukum yang belum ditetapkan oleh al-Qur'an.1

Hadis sebagai sumber kedua, nampaknya selalu menarik untuk dikaji, baik yang menyangkut tentang kritik otentitas atau validitas (sanad dan matan) maupun metodologi pemahaman (syarh) hadis itu sendiri.

Para ulama dahulu telah banyak mencoba melakukan penafsiran atau pemahaman hadis yang terdapat dalam al-Kutub al-Sittah, yakni dengan menulis kitab syarah terhadap kitab tersebut.

Meskipun demikian, upaya untuk menemukan metode yang digunakan ulama dalam penyusunan kitab syarah hadis tersebut hampir-hampir tidak pernah tersentuh. Namun dari beberapa metode yang dipergunakan oleh para ulama dalam menyusun kitab syarh tersebut dapat

1 Said Agil Husain Munawwar dan Abdul Mustaqim. 2001. Asbabul Wurud. Yogyakarta: Pustaka Pelajar., hal. 24. 
diklasifikasikan beberapa metode pemahaman hadis, yakni metode tahlili, metode ijmāti, dan metode muqārin.2

\section{PEMBAHASAN}

\section{A. Metodologi Pemahaman Hadis}

\section{Metode dan Metodologi}

Kata "metode" berasal dari bahasa Yunani methodos, yang berarti cara atau jalan.3 Dalam bahasa Inggris, kata ini ditulis method, dan bangsa Arab menerjemahkannya dengn thariqat dan manhaj. Dalam bahasa Indonesia, kata tersebut mengandung arti: cara teratur yang digunakan untuk melaksanakan suatu pekerjaan agar tercapai sesuai dengan yang dikehendaki; cara kerja yang bersistem untuk memudahkan pelaksanaan suatu kegiatan guna mencapai tujuan yang ditentukan.4 Sedangkan metodologi berasal dari bahasa Yunani methodos yang berarti cara atau jalan, logos artinya ilmu. Kata metodologi dalam Kamus Besar Bahasa Indosesia diartikan sebagai ilmu tentang metode; uraian tentang metode. 5

\section{Pemahaman (Syarh)}

Kata syarah (Syarh) berasal dari bahasa Arab, Syaraha-Yasyrahu-Syarhan yang artinya menerangkan, membukakan, melapangkan.6 Istilah syarh (pemahaman) biasanya digunakan untuk hadis, sedangkan tafsir untuk kajian al-Qur'an. Dengan kata lain, secara substansial keduanya sama (sama-sama menjelaskan maksud, arti atau pesan); tetapi secara istilah, keduanya berbeda. Istilah tafsir (tafsir) spesifik bagi al-Qur'an (menjelaskan maksud, arti, kandungan, atau pesan ayat alQur'an), sedangkan istilah syarah (syarh) meliputi hadis (menjelaskan maksud, arti, kandungan, atau pesan hadis) dan disiplin ilmu lain.7

2 Metode ini diadopsi dari metode penafsiran Al-Qur'an dengan melihat karakter persamaan yang terdapat antara penafsiran Al-Qur'an dan penafsiran atau syarh hadis. Artinya metode penafsiran Al-Qur'an dapat diterapkan dalam syarh hadis dengan mengubah redaksi/kata Al-Qur'an menjadi hadis; tafsir menjadi syarh. (baca Nizar Ali. 2001. Memahami Hadis Nabi (Metode dan Pendekatan). Yogyakarta: Center for Educational Studies and Development (CESaD) YPI Al-Rahmah., hal. 28.

Dalam studi tafsir telah dijumpai beberapa teori tentang tafsir Al-Qur'an dengan melihat metode dan corak penafsiran yang dipakai oleh para ulama tafsir dalam kitab-kitab tafsir. Ada 4 (empat) metoden penafsiran, yaitu: metode tafsir tahlîlî (analitis), metode tafsir ijmâlî (global), metode tafsir muqârin (perbandingan) dan metode tafsir maudhûi (tematik). Ibid., hal. 28, atau baca Nashrudin Baidan. 2000. Metodologi Penafsiran Al-Qur'an. Yogyakarta: Pustaka Pelajar.

3 Ibid.,hal. 1 atau baca Fuad Hasan dan Koentjaraningrat. 1997. Beberapa Asas Metodologi Ilmiah, dalam Koentjaraningrat (ed.), Metode-metode Penelitian Masyarakat. Jakarta: Gramedia., hal. 16.

4 Tim Penyusun Kamus Pusat Bahasa KBBI. 2005. Kamus Besar Bahasa Indonesia. jakarta: Balai Pustaka. Cetakan ketiga, edisi III., hal. 740.

5 Ibid., hal. 741.

6 Mahmud Yunus. 1973. Kamus Arab-Indonesia. Jakarta: Yayasan Penyelenggara Penterjemah Penafsir Al-Qur'an.,hal.

7 Nizar Ali., op.cit., hal 28. 
Jadi maksud dari metodologi pemahaman (syarh) hadis ialah ilmu tentang metode memahami hadis. Dengan demikian, kita dapat membedakan antara dua istilah, yakni metode syarh: cara-cara memahami hadis, sementara metodologi syarh: ilmu tentang cara tersebut. Metode yang digunakan oleh pensyarahan hadis ada tiga, yaitu metode tahlili, metode ijmāili, dan metode muqārin. Adapun untuk melihat kitab dari sisi bentuk pensyarahan, digunakan teori bentuk syarh bi al-masur dan syarh bi al-ra’y. Sedangkan dalam menganalisis corak kitab digunakan teori kategorisasi bentuk syarh fiqhy, falsafy, sufy, atau lugawy.8

\section{B. Metode-Metode Pemahaman (Syarh) Hadis}

\section{Metode Tahlili (Analitis)}

\section{a. Pengertian}

Metode syarh tahlili adalah menjelaskan hadis-hadis Nabi dengan memaparkan segala aspek yang terkandung dalam hadis tersebut serta menerangkan makna-makna yang tercangkup di dalamnya sesuai dengan kecenderungan dan keahlian pensyarah. 9

Dalam menyajikan penjelasan atau komentar, seorang pensyarah hadis mengikuti sistematika hadis sesuai dengan urutan hadis yang terdapat dalam sebuah kitab hadis yang dikenal dari al-Kutub al-Sittah

Pensyarah memulai penjelasannya dari kalimat demi kalimat, hadis demi hadis secara berurutan. uraian tersebut menyangkut berbagai aspek yang dikandung hadis seperti kosa kata, konotasi kalimatnya, latar belakang turunnya hadis (jika ditemukan), kaitannya dengan hadis lain, dan pendapat-pendapat yang beredar di sekitar pemahaman hadis tersebut, baik yang berasal dari sahabat, para tabi'in maupun para ulama hadis. 10

\section{b. Ciri-ciri Metode Tahlili}

Secara umum kitab-kitab syarah yang menggunakan metode tahlili biasanya berbentuk ma'sur (riwayat) atau ra'y (pemikiran rasional). Syarah yang berbentuk ma'sur ditandai dengan banyaknya dominasi riwayat-riwayat yang datang dari sahabat, tabi'in atau ulama hadis. Sementara syarah yang berbentuk ra'y banyak didominasi oleh pemikiran rasional pensyarahnya.

Kitab-kitab syarah yang menggunakan metode tahlili mempunyai ciri-ciri sebagai berikut :

1) Pensyarahan yang dilakukan menggunakan pola menjelaskan makna yang terkandung di dalam hadis secara komprehensif dan menyeluruh.

2) Dalam pensyarahan, hadis dijelaskan kata demi kata, kalimat demi kalimat secara berurutan serta tidak terlewatkan juga menerangkan sabab al wurûd dari hadis-hadis yang dipahami jika hadis tersebut memiliki sabab wurûdnya.

8 Nizar Ali. 2007. (Ringkasan Desertasi) Kontribusi Imam Nawawi dalam Penulisan Syarh Hadis. Yogyakarta., hal. 4.

9 Nizar Ali.,op.cit., hal. 29 atau baca Abd al-Hay al-Farmâwi.1997. Al-Bidâyah fí al-Tafsîr al-Maudhû̉ 'i. ,t.tp: Matba'ah al-Hadharah al-'Arabiyyah., hal.24.

10 Ibid, hal. 29. 
3) Diuraikan pula pemahaman-pemahaman yang pernah disampaikan oleh para sahabat, tabi' in dan para ahli syarah hadis lainnya dari berbagai disiplin ilmu.

4) Di samping itu dijelaskan juga munāsabah (hubungan) antara satu hadis dengan hadiis lain.

5) Selain itu, kadang kala syarah dengan metode ini diwamai kecenderungan pensyarah pada salah satu mazhab tertentu, sehingga timbul berbagai corak pensyarahan, seperti corak fiqhy dan corak lain yang dikenal dalam bidang pemikiran Islam.11

c. Contoh

Dalam kitab syarah hadis fathh al-Bärì bi Syarh Sahih al-Bukhāri terhadap hadis al-Bukhari sebagai berikut:12

حدثنا الحميدي عبد الله بن الزبير قال حدثنا يحيى بن سعيد الأنصاري قال أخبرني محمد ابن إبراهيم التيمي أنه سمع علقة بن وقاص الليثي يقول سمعت عمر بن الخطاب رضي الله عنه على المنبر

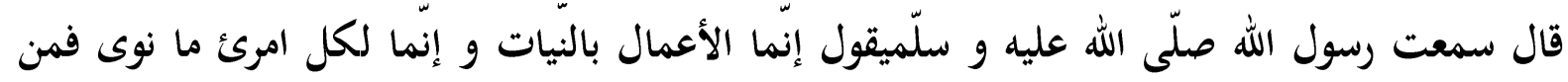
كانت هجرته الى دنيا يصيبها أو إلى امرأة ينكحها فهجرته إلى ما هجر إليه. قوله حدثنا (الحميدي (هو أبو بكر(عبد الله بن الزبير) بن عيسى منسوب إلى حميد بن أسامة بطن من بني أسد بن عبد العزى بن قصي رهط خديجة زوج النبي صلّى الله عليه و سلّم يجتمع معها في أسد ويجتمع مع النّي صلّى الله عليه وسلّم في قصي وهو إمام كبير مصنف رافق الثافعي في الطلب عن بن الن عيينة وطبقته و أخذ عنه الفقه و رحل معه إلى مصر ورجع بعد وفاته كلى مكة فلى أن مات بها سنة تسع عشرة و مائتين فكأن البخاري امتثل قوله صلّى الله عليه و سلّم قدموا قريشا فافتتح كتابه بالرواية عن الحميدي لكونه أفقه قرشي أخذ عنه و له مناسبة أخرى لأنه مكي كشيخه فناسب أن يذكر في أول ترجمة بدء الوحي لأن ابتداءه كان بمكة ومن ثم ثنى بالرواية عن مالك لأنه شيخ أهل المدينة وهي تالية لمكة في نزول الوحي و في جميع الفضلل و مالك و ابن عيينة قرينان قال الشّافعي لولاهما لذهب العلم من الحجاز قوله (حدثنا سفيان) هو ابن عيينة بن أبي عمران الهلالي أبو محمد المكي أصله و مولده الكوفة و قد شارك مالكا في كثير من شيوخه و عاش بعده عشرين سنة وكان يذكر أنه سمع من سبعين من التابعين قوله (عن يحي بن سعيد) حدثنا يحي بن سعيد (الأنصاري) اسم جده قيس بن عمرو و هو صحابي و يحي من صغار التابعين و شيخهل(محمد بن إبراهيم) بن الحارث بن خالد (التيمي) من أوساط التّابعين....والله اعلم. وقد اعترض على المصنف في إدخاله حديث الأعمال هذا في ترجمة بدء الوحي و أنه لا تعلق له به أصلا بحيث أن الخطابي في شرخه و الإسماعيلي في مستخرجه أخرجاه قبل الترجمة لاعتقادهما أنه

11 Ibid., hal.30-31.

12 Ibid.,hal. 31 atau Al-Asqalânî, Fath al-Bârî Sahih al-Bukhâri. Beirut: Dâr al-Ma'rifah. Jilid 1., hal. 1018. 
إنما أورده للتبرك به فقد واستصوب أبو القاسم بن منده صنيع الإسماعيلي في ذلك وقال بن رشيد لم

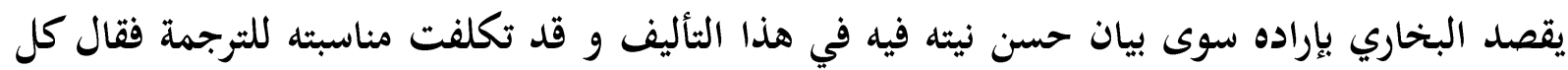

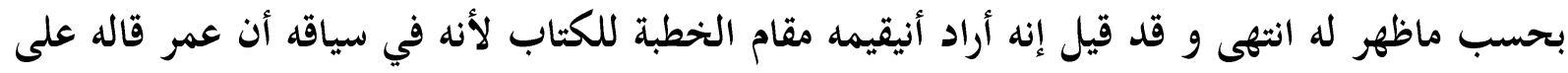

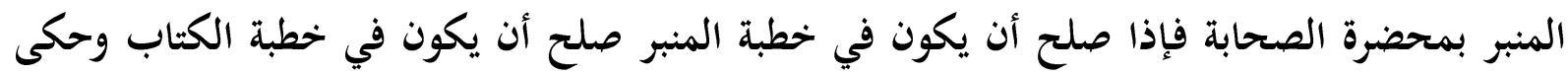

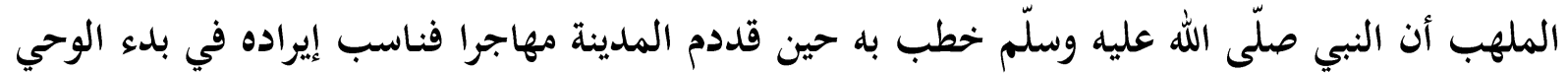

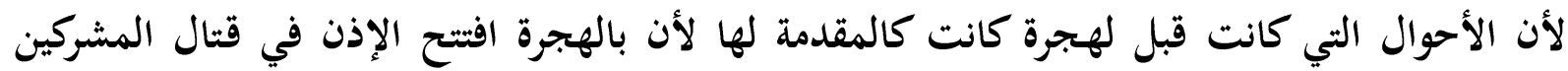
ويعقبه النصر والظفر والفتح انتهى وهذا وجه حسن إلا أنني لأم أر ماذكره من كونه صلى لهالى الله عليه وسلم

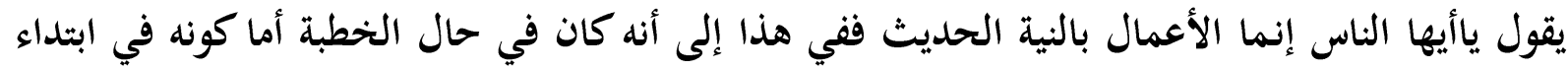

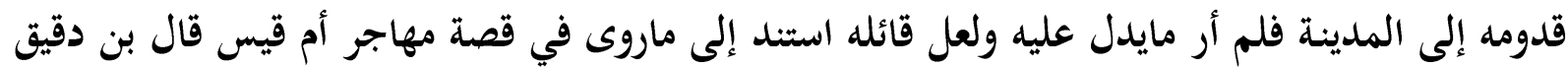
العيد نقلوا أن رجلا هاجر من مكة إلى المدينة لا يريد بذلك فضيلة...

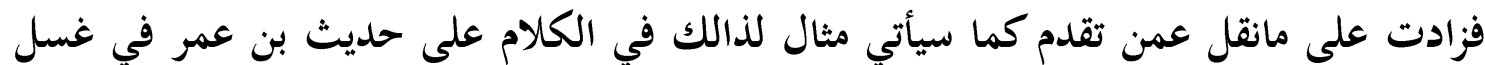

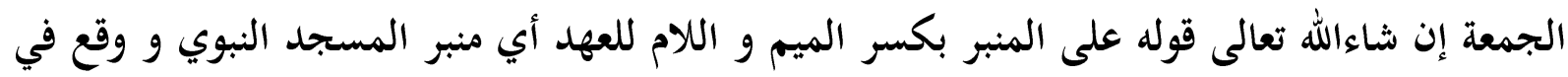

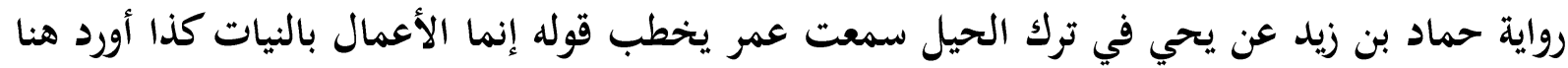
وهو من مقابلة الجمع بالجمع أي كل عمل بنيته و قال الخوبي كأنه أشار بذلك إلى إنى أن النية تتنوع كما

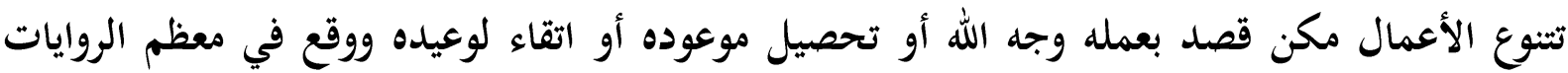
بإفراد النية ووجه أن محل النية القلب وهو متحد فناسب افرادها بخلاف الأعمال فأنها متعلقة بالظواهر و هي متعددة فناسب جمعها ولأن النية ترجع إلى الإخلاص وهو واحد للواحد الذي لا شريك له ووقع في

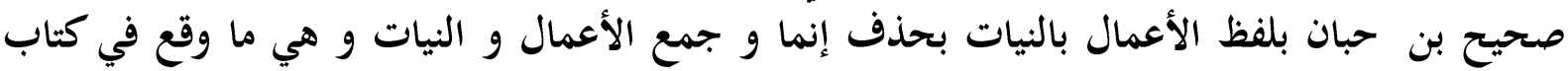

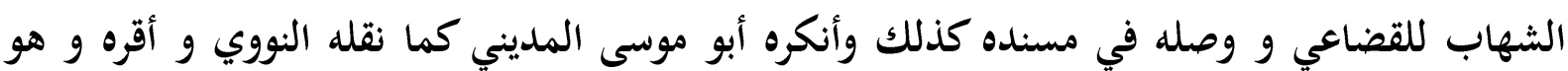

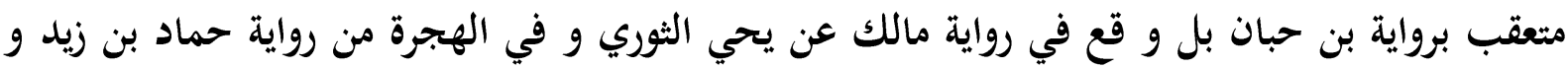

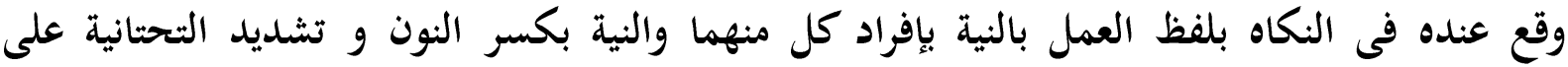
المشهور و في بعض اللغات بتحفيفها قال الرماني قوله إنما الأعمال بالنيات هذا التركيب يفيد الحصر عند المحققين و اختلف في وجه افادته فقيل لأن الأعمال جمع محلى بالألف و اللام مفيد للاستغراق و هو ملتزم للقصر لأن معناه كل عمل بنية فلا عمل الا بنية و قيل لأن إنما للحصر و هل افادتها له بالمنطوق أو بالمفهوم أو تفيد الحصر بالوضع أو العرف أو تفيده بالحقيقة أو المجاز ....الى الأخر

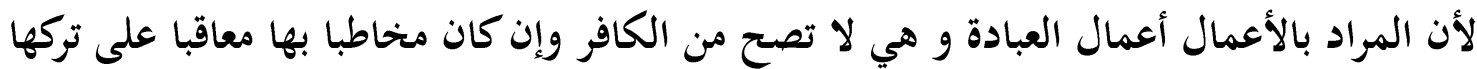

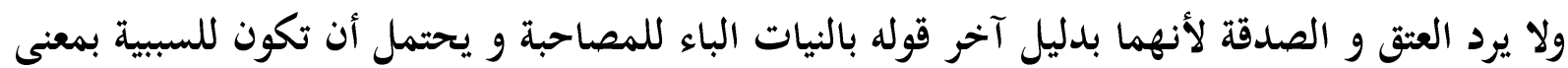
أنها مقومة للعمل فكأنها سبب في ايجاده و على الأول فهي من نفس العمل فيثترط أن لا تتخلف عن بهن 


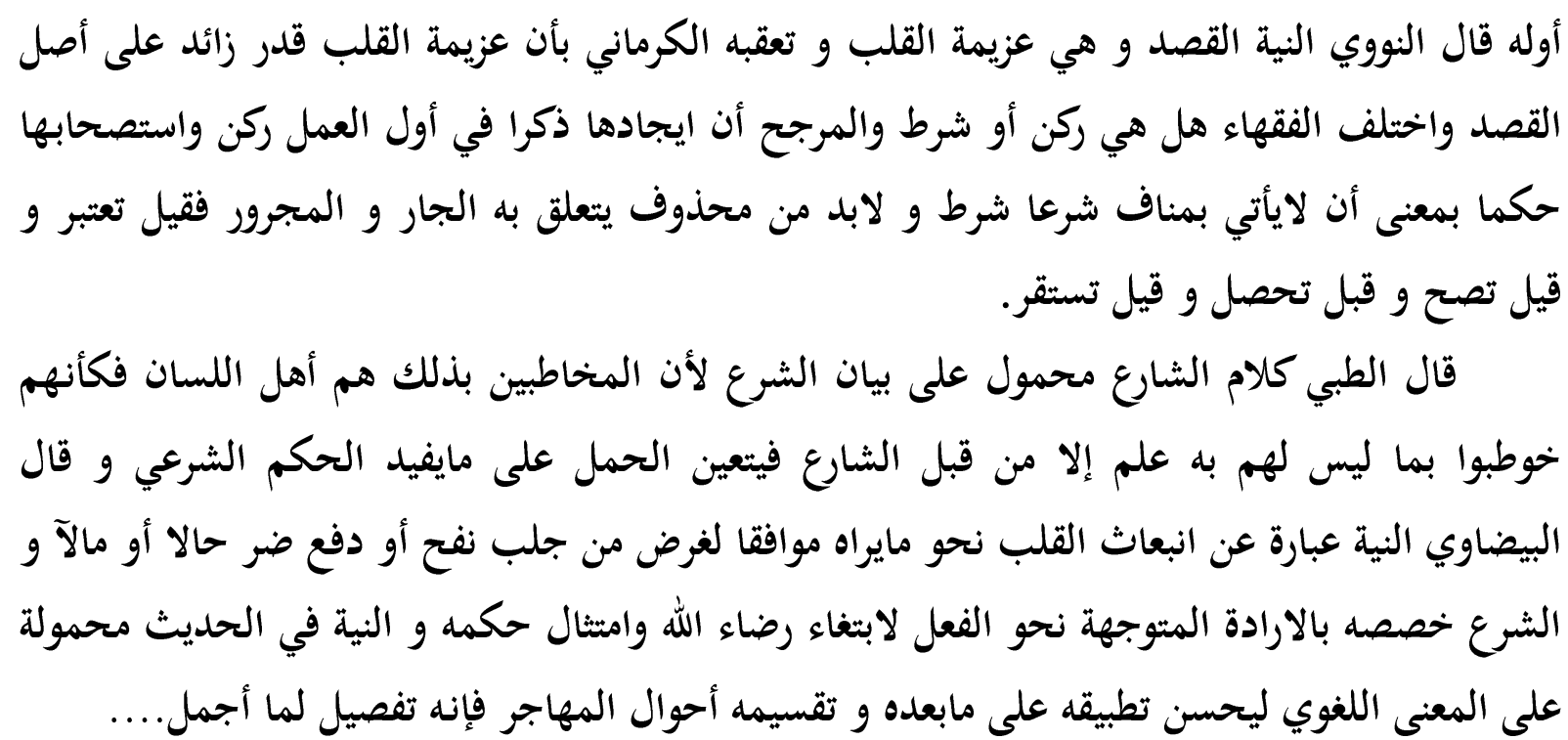

Dari kutipan syarah di atas dapat diketahui bahwa dalam menerangkan hadis, pensyarah mengemukakan analisis tentang periwayat (râwî̉) sesuai dengan urutan sanad, sabab al-wurûd, juga menyajikan hadis-hadis lain yang berhubungan dengan hadis tersebut, bahkan ayat al-Qur'an yang berkenaan dengan hadis. Pensyarah menggunakan riwayat riwayat dari para ulama. Syarah banyak didominasi oleh pendapat mereka, sehingga dari uraian yang demikian panjang, pendapat dari pensyarah hampir-hampir tidak diketemukan. Selain itu juga, disajikan penjelasan kosa kata yang terdapat didalamnya. Dengan demikian dapat disimpulkan bahwa meskipun syarah yang memakai metode analitis ini mengandung uraian yanglebih rinci, namun karena berbentuk al-ma'tsur, pendapat dari pensyarah tetap sukar ditemukan. Inilah salah satu ciri utama yang membedakan secara mencolok dengan Syarh bi-al-ra'y. 13

\section{d. Kelebihan dan Kekurangan Metode TahFili}

\section{1) Kelebihan}

a) Ruang lingkup pembahasan yang sangat luas

Metode analitis dapat menyakup berbagai aspek: kata, frasa, kalimat, sabab al wurûd, munāsabah (munasabah internal) dan lain sebagainya.

b) Memuat berbagai ide dan gagasan

Memberikan kesempatan yang sangat longgar kepada pensyarah untuk menuangkan ide-ide, gagasan-gagasan yang pernah dikemukakan oleh para ulama.

\section{2) Kekurangan}

a) Menjadikan petunjuk hadis parsial

Metode analitis menjadikan petunjuk hadis bersifat parsial atau terpecah-pecah, sehingga seolah-olah hadis memberikan pedoman secara tidak utuh dan tidak konsisten karena syarah yang diberikan pada hadis lain yang sama karena kurang 
memperhatikan hadis lain yang mirip atau sama redaksinya dengannya.

b) Melahirkan syarah yang subyektif

Dalam metode analitis, pensyarah tidak sadar bahwa dia telah mensyarah hadis secara subyektif, dan tidak mustahil pula ada di antara mereka yang mensyarah hadis sesuai dengan kemauan pribadinya tanpa mengindahkan kaidah-kaidah atau normanorma yang berlaku. 14

\section{Metode IjmāIi (Global)}

\section{a. Pengertian}

Metode $i j m a \bar{a} i$ (global) adalah menjelaskan atau menerangkan hadis-hadis sesuai dengan urutan dalam kitab hadis yang ada dalam al-Kutub al-Sittah secara ringkas, tapi dapat merepresentasikan malrna literal hadis dengan bahasa yang mudah dimengerti dan gampang dipahami. 15

\section{b. Ciri-ciri Metode Ijmāli 16}

1) Pensyarah langsung melakukan penjelasan hadis dari awal sampai akhir tanpa perbandingan dan penetapan judul.

2) Penjelasan umum dan sangat ringkas.

3) Pensyarah tidak memiliki ruang untuk mengemukakan pendapat sebanyak-banyaknya. Namun demikian, penjelasan terhadap hadis-hadis tertentu juga diberikan agak luas, tetapi tidak seluas metode tahlili.

\section{c. Contoh}

Dalam kitab syarah hadis 'Aun al-Ma'bud Syarh Sunan Abī Dāwud karya Muhammad bin Asyraf bin 'Ali Haidar Al-Ṣiddiqīi al-'Aẓ̌im Ābādì sebagai berikut:17

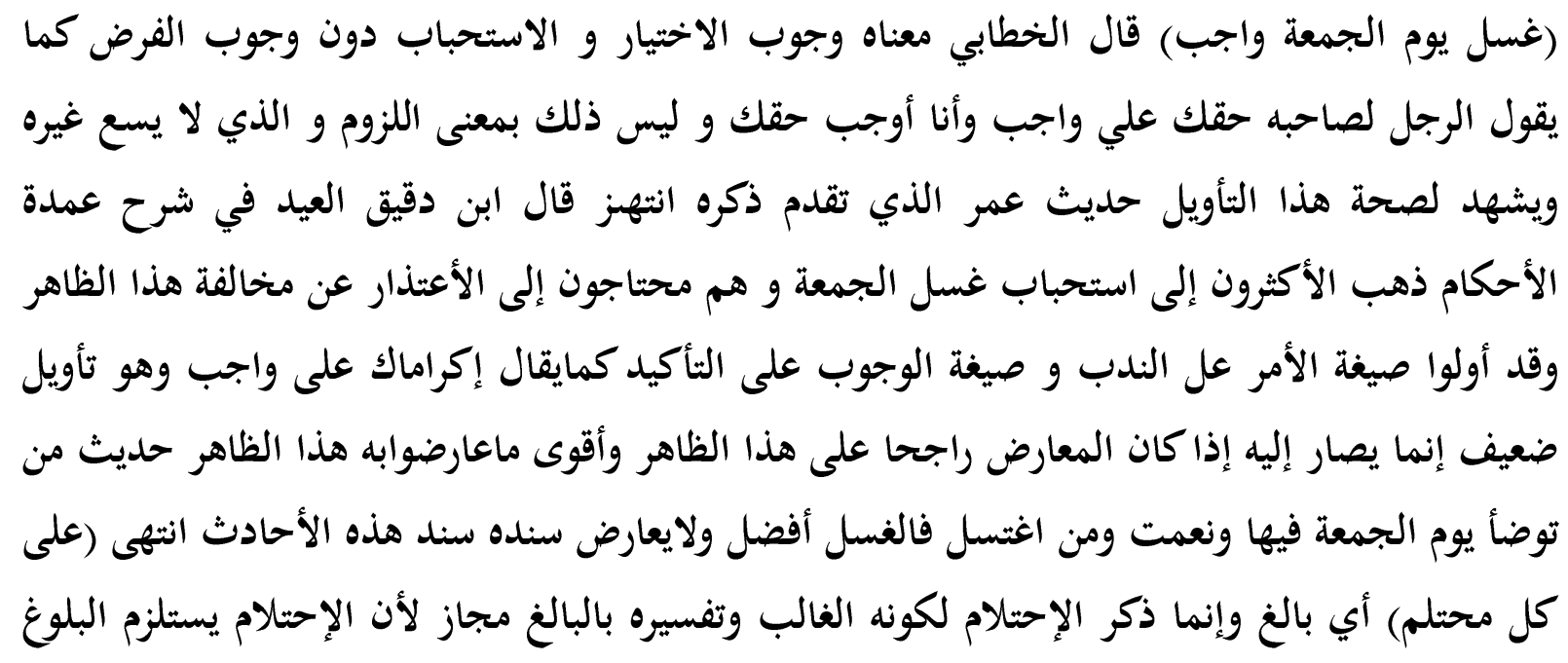

14 Ibid., hal 38-39.

15 Ibid., hal. 42.

16 Ibid., hal. 43.

17 Ibid., hal. 43 atau Muhammad bin Asyraf bin 'Ali Haidar Al-Siddîqî al-'Azîm Âbâdî. 1979. 'Aun alMa’bud Syarh Sunan Abî Dâwud. Beirut: Dâr al-Fikr., hal. 5-6. 


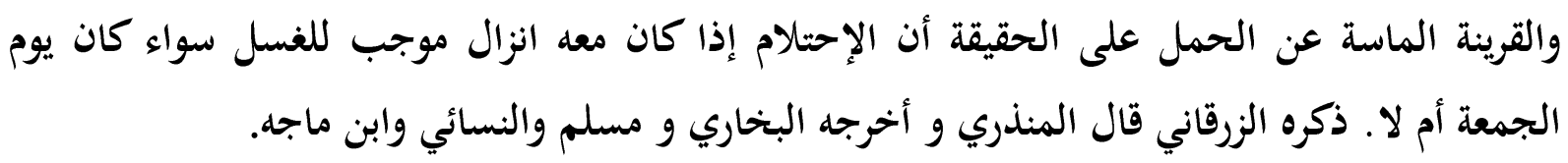

d. Kelebihan dan Kekurangan

1) Kelebihan

a) Ringkas dan padat

Metode ini terasa lebih praktis dan singkat sehingga dapat segera diserap oleh pembacanya. Syarah tidak bertele-tele, sanad dan kritik matan sangat minim.

b) Bahasa Mudah

Pensyarah langsung menjelaskan kata atau maksud hadis dengan tidak mengemukakan ide atau pendapatnya secara pribadi.

2) Kekurangan

a) Menjadikan petunjuk hadis bersifat parsial

Metode ini tidak mendukung pemahaman hadis secara utuh dan dapat menjadikan petunjuk hadis bersifat parsial tidak terkait satu dengan yang lain, sehingga hadis yang bersifat umum atau samar tidak dapat diperjelas dengan hadis yang sifatnya rinci.

b) Tidak ada ruang untuk mengemukakan analisis yang memadai.

Metode ini tidak mnyediakan ruangan yang memuaskan berkenaan dengan wacana pluralitas pemahaman suatu hadis. 18

\section{Metode Muqārin (komparatif)}

\section{a. Pengertian}

Metode Muqārin adalah metode memahami hadis dengan cara: (1) membandingkan hadis yang memiliki redaksi yang sama atau mirip dalam kasus yang sama atau memiliki redaksi yang berbeda dalam kasus yang sama. (2) Membandingkan berbagai pendapat ulama syarah dalam mensyarah hadis. 19

Jadi metode ini dalam memahami hadis tidak hanya membandingkan badis dengan hadis lain, tetapi juga membandingkan pendapat para ulama (pensyarah) dalam mensyarah hadis.

Di antara Kitab yang menggunakan metode muqārin ini adalah Șahīh Muslim bi Syarh alNawawī karya Imam Nawawī, Umdah al-Qāri Syarh Șahīh al-Bukhārī karya Badr al-Din Abû Muhammad Mahmûd al-'Aini, dan lain-lain

\section{b. Ciri-ciri Metode Muqārin}

1) Membandingkan analitis redaksional (mabāhis lafz̈iyyah) dan perbandingan periwayat periwayat, kandungan makna dari masing-masing hadis yang diperbandingkan.

2) Membahas perbandingan berbagai hal yang dibicarakan oleh hadis tersebut.

18 Ibid., hal.44-46.

19 Ibid.,hal. 46. 
3) Perbandingan pendapat para pensyarah mencakup ruang lingkup yang sangat luas karena uraiannya membicarakan berbagai aspek, baik menyangkut kandungan (makna) hadis maupun korelasi (munāsabah) antara hadis dengan hadis. 20

Ciri utama metode ini adalah perbandingan, yakni membandingkan hams dengan hadis, dan pendapat ulama syarah dalam mensyarah hadis.

\section{c. Urutan Metode Muqārin}

Metode ini diawali dengan menjelaskan pemakaian mufradat (suku kata), urutan kata, kemiripan redaksi. Jika yang akan diperbandingkan adalah kemiripan redaksi misalnya, maka langkah-yang ditempuh sebagai berikut :

1) Mengidentifikasi dan menghimpun hadis yang redaksinya bermiripan.

2) Memperbandingkan antara hadis yang redaksinya mirip tersebut, yang membicarakan satu kasus yang sama, atau dua kasus yang berbeda dalam satu redaksi yang sama.

3) Menganalisa perbedaan yang terkandung di dalam berbagai redaksi yang mirip, baik perbedaan itu mengenai konotasi hadis maupun redaksinya, seperti berbeda dalam menggunakan kata dan susunannya dalam hadis, dan sebagainya.

4) Memperbandingkan antara berbagai pendapat para pensyarah tentang hadis yang dijadikan objek bahasan.21

\section{d. Contoh}

Salah satu kitab yang menggunakan Syarh muqārin adalah Umdah al-Qärī Syarh Șahīh alBukhārī karya Badr al-Dīn Abû Muhammad Mahmûd bin Ahmad al-'Ainī.22

قد حصل من الطرق المذكورة أربعة ألفاظ "إنما الأعمال بالنيات" و" الأعمال بالنية" و "العمل

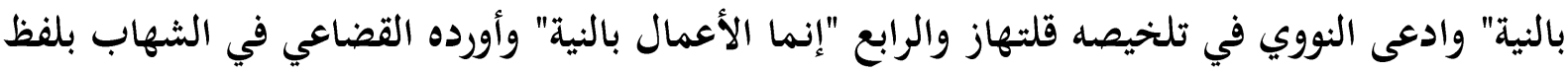

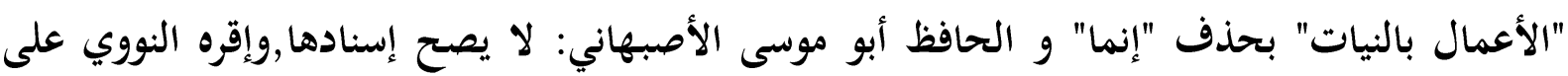

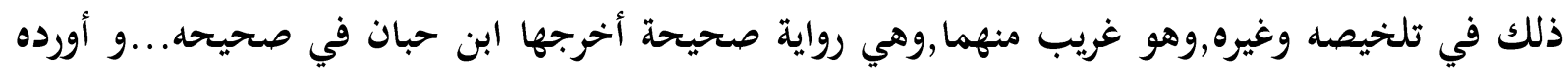

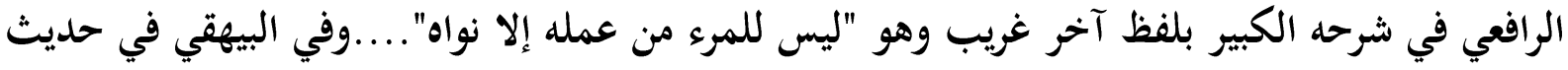
آخر مرفوعا"لا عمل لمن لا نية له.....لكن اسناده جهالة.

الأول: احتجت الأئمة الثلاثة في وجوب لهيل النية في الوضوء والغسل فقالوا: التقدير فيه صحة

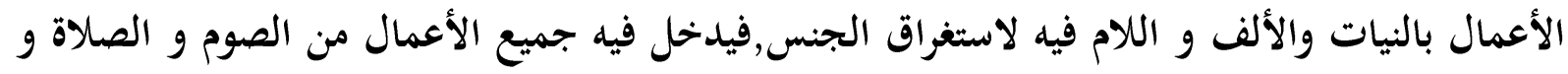

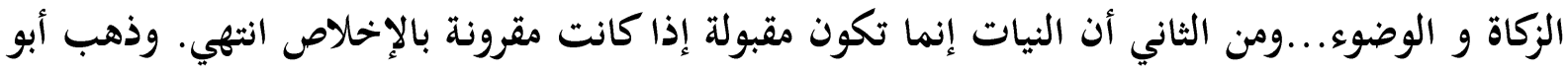
حنيفة و أبو يوسف و محمد و زفر والنواوي والأوزاعي و الحسن بن حي ومالك في رواية إلى أن الوضوء

22 Ibid.,hal.49 atau Badr al-Dîn Abû Muhammad Mahmûd bin Ahmad al-'Ainî,1972. Syarh muqârîn adalah Umdah al-Qârî Syarh Sahîh al-Bukhârî, . Aleppo: Mustafâ al-bâbî al-Halabi., hal. 24, 33-34. 


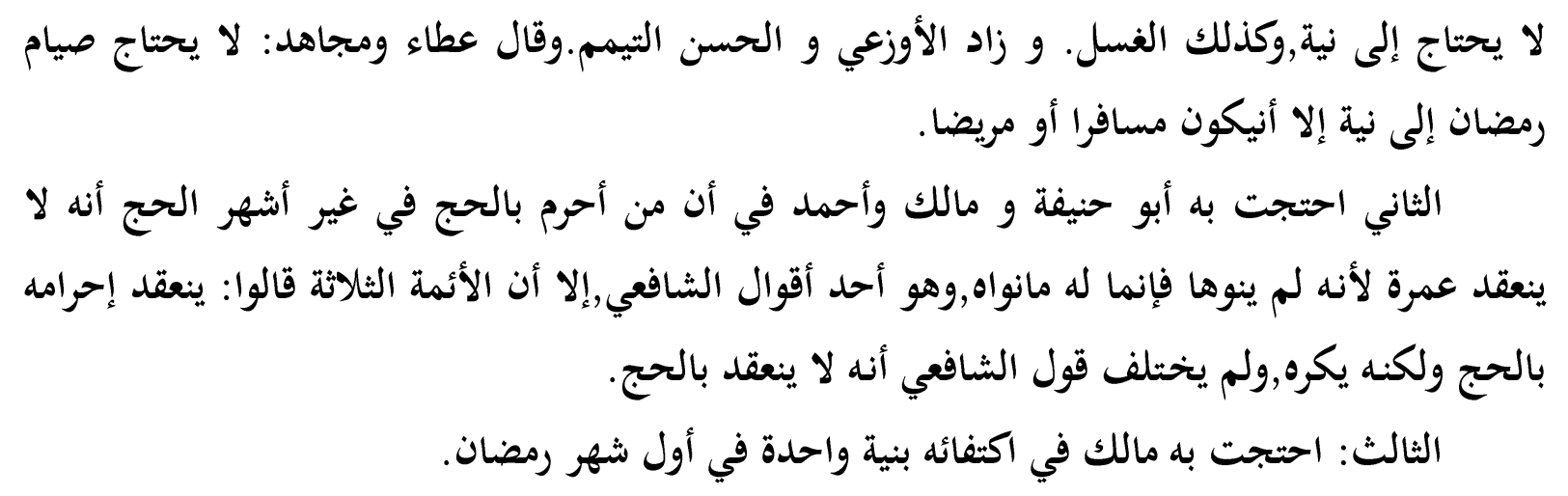

\section{e. Kelebihan dan Kekurangan}

1) Kelebihan

a) Memberikan wawasan pemahaman yang relatif lebih luas kepada para pembaca bila dibandingkan denga metode lain.

b) Membuka pintu untuk selalu bersikap toleran terhadap pendapat orang lain yang terkadang jauh berbeda.

c) Pemahaman dengan metode muqarin sangat berguna bagi mereka yang ingin mengetahui berbagai pendapat tentang sebuah hadis.

d) Pensyarah didorong untuk mengkaji berbagai hadis serta pendapatpendapat para pensyarah lainnya.

\section{2) Kekurangan}

a) Metode ini tidak relevan bagi pembaca tingkat pemula, karena pembahasan yang dikemukakan terlalu luas sehingga sulit untuk menentukan pilihan.

b) Metode ini tidak dapat diandalkan untuk menjawab permasalah sosial yang berkembang di tengah masyarakat, karena pensyarah lebih mengedepankan perbandingan daripada pemecahan masalah.

c) Metode ini terkesan lebih banyak menelusuri pemahaman yang pernah diberikan oleh mama daripada mengemukakan pendapat baru23.

Untuk dapat memahami hadis dengan tepat, kelengkapan ilmu bantu mutlak diperlukan. Berkaitan dengan ilmu bantu daIam memahami hadis, Yusuf Al Qardawi memberikan beberapa pedoman, yaitu24:

a) Mengetahui petunjuk Al Qur'an yang berkenaan dengan hadis tersebut.

b) Menghimpun hadis-hadis yang se-tema.

c) Menggabungkan dan mentarjihkan antar hadis-hadis yang tampak bertentangan.

d) Mempertimbangkan latar belakang, situasi dan kondisi hadis ketika diucapkan diperbuat serta tujuaannya.

24 Ibid., hlm. 25 atau baca Yusuf al-Qardhawi, 1993. Bagaimana Memahami Hadis Nabi saw. edisi terjemahan (Bandung: Kharisma), hlm. 92 
e) Mampu membedakan antara sasaran yang berubah-ubah dengan sasaran yang tetap.

f) Mampu membedakan antara ungkapan yang bermakna sebenarnya dan bersifat metafora.

g) Mampu membedakan antara hadis yang berkenaan dengan alam gaib (kasat mata) dengan yang tembus pandang.

h) Mampu memastikan makna dan konotasi kata-kata dalam hadis.

\section{KESIMPULAN}

Dalam metode pemahaman (syarh) hadis, para ulama menggunakan 3 metode, yaitu metode tahlïi (analitis), metode ijmā $\bar{l}$ (global), dan metode muqārin (perbandingan). Ibarat gading tak retak, ketiga metode itu mempunyai kelebihan maupun kelemahan masing-masing. Dengan perkembangan ilmu pengetahuan, maka tak diragukan lagi akan muncul metode maupun pendekatan baru untuk memahami hadis, karena hadis merupakan salah satu sumber pokok hukum Islam kedua setelah alQur'an tak kan lepas dari kajian maupun penelitian. Wallahu'alam bi al-ṣầāb.

\section{DAFTAR PUSTAKA}

Al-Asqalānì, Fath al-Bārī Shahih al-Bukhāri. Beirut: Dār al-Ma’rifah. Jilid 1.

Agil Husain Munawwar, Said dan Mustaqim. 2001. Abdul. Asbabul Wurud. Yogyakarta: Pustaka Pelajar.

Ali, Nizar. 2001. Memahami Hadis Nabi (Metode dan Pendekatan). Yogyakarta: Center for Educational Studies and Development (CESAD) YPI Al-Rahmah.

2007. (Ringkasan Desertasi) Kontribusi Imam Nawawi dalam Penulisan Syarh Hadis. Yogyakarta.

Baidan, Nashrudin. 2000. Metodologi Penafsiran Al-Qur'an. Yogyakarta: Pustaka Pelajar.

al-Dīn Abû Muhammad Mahmûd bin Ahmad al-'Aini, Badr. 1972. Syarh muqārin adalah Umdah alQàrī Syarh Ṣahīh al-Bukhārī,. Aleppo: Mustafā al-bābī al-Halabi.

al-Hay al-Farmāwi, Abd. 1997. Al-Bidāyah fỉ al-Tafsìr al-Maudû̀'i. ,t.tp: Matba'ah al-Hadharah al'Arabiyyah.

Hasan, Fuad dan Koentjaraningrat. 1997. Beberapa Asas Metodologi Ilmiah, dalam Koentjaraningrat (ed.), Metode-metode Penelitian Masyarakat. Jakarta: Gramedia.

Tim Penyusun Kamus Pusat Bahasa KBBI. 2005. Kamus Besar Bahasa Indonesia. Jakarta: Balai Pustaka. Cetakan ketiga, edisi III.

Yunus, Mahmud. 1973. Kamus Arab-Indonesia. Jakarta: Yayasan Penyelenggara Penterjemah Penafsir Al-Qur'an.

Al-Qardhawi, Yusuf. 1993. Bagaimana Memahami Hadis Nabi saw. edisi terjemahan Bandung: Kharisma. 